Grzegorz MaśLOCH

Szkoła Główna Handlowa, Warszawa, Polska

\title{
Przedsiębiorstwa paneuropejskie wobec konsolidacji, fuzji i przejęć a gospodarka Polski: szansa czy wykluczenie z gry o rozwój?
}

\author{
Pan-European Companies Towards Consolidation, \\ Mergers and Acquisitions and the Polish Economy: \\ A Chance or Exclusion from Game Development?
}

Streszczenie: Sprostanie wyzwaniom współczesności wymaga wprowadzania innowacyjności i nowych technik oraz metod zarządzania, a przede wszystkim zmiany struktur organizacyjnych na rzecz rozwiązań elastycznych. Wychodząc naprzeciw tym wyzwaniom UE zaproponowała paneuropejskie formy prawne prowadzenia działalności gospodarczej, których celem jest nie tylko ujednolicenie wspólnego rynku, ale także zwiększenie konkurencyjności europejskich przedsiębiorstw i pobudzenie przedsiębiorczości wśród mieszkańców.

Dlatego też celem artykułu jest omówienie roli i znaczenia paneuropejskich form prowadzenia działalności gospodarczej dla funkcjonowania europejskich przedsiębiorstw, ich konsolidacji, fuzji i przejęć, a także wyzwań jakie stawiają one przed polską gospodarką.

\begin{abstract}
Meeting the challenges of the present time requires introduction of innovation, new management techniques and methods, and above all, changes of organizational structures for the sake of flexible solutions. To meet these challenges, the EU proposed pan-European legal forms of running a business, whose aim is not only to unify the common market, but also to increase the competitiveness of European companies, as well as stimulate entrepreneurship among inhabitants.

Therefore, the aim of this article is to discuss the role and importance of pan-European forms of running a business for the functioning of European companies, their consolidation, mergers and acquisitions and the challenges they pose to the Polish economy.
\end{abstract}

Słowa kluczowe: Unia Europejska, formy prawne przedsiębiorstw, konsolidacja, fuzje i przejęcia

Key words: European Union, types of business entity, consolidation, mergers and acquisitions 


\section{WSTĘP}

Zachodzące procesy globalizacyjne sprawiają, że gospodarki poszczególnych państw są ze sobą coraz bardziej powiązane i od siebie współzależne.

Każdy kraj musi zmierzyć się z problemami, jakie stawia przed nim świat coraz ściślejszych powiązań i wzajemnych zależności (Rifkin 2005: 222). Nowe wyzwania stoją zwłaszcza przed poszczególnymi państwami i funkcjonującymi na ich terytorium przedsiębiorstwami, które muszą dostosowywać się do dynamicznych przemian demograficznych, społecznych i gospodarczych.

Sprostanie wyzwaniom współczesności wymaga wprowadzania innowacyjności i nowych technik oraz metod zarządzania, a przede wszystkim zmiany struktur organizacyjnych na rzecz rozwiązań elastycznych. Wychodząc naprzeciw tym wyzwaniom UE zaproponowała paneuropejskie formy prawne prowadzenia działalności gospodarczej, których celem jest nie tylko ujednolicenie wspólnego rynku, ale także zwiększenie konkurencyjności europejskich przedsiębiorstw i pobudzenie przedsiębiorczości wśród mieszkańców. Dlatego też celem artykułu jest omówienie roli i znaczenia paneuropejskich form prowadzenia działalności gospodarczej dla funkcjonowania europejskich przedsiębiorstw, ich konsolidacji, fuzji i przejęć, a także wyzwań jakie stawiają one przed polską gospodarką.

\section{SwOBODA PRZEDSIĘBIORCZOŚCI W UE}

Jednolity rynek, najbardziej konkretne osiągnięcie UE, może pomóc Europie w sprostaniu wyzwaniom XXI wieku. Otwarty, zintegrowany i konkurencyjny jednolity rynek, stymulować będzie wzrost gospodarczy i stosunki handlowe oparte na zdrowych zasadach, otwierając możliwości i tworząc miejsca pracy (Jednolity 2007: 15-16).

Idea jednolitego rynku w UE jest wyrażona m.in. w zapisach Traktatu o funkcjonowaniu Unii Europejskiej (TFUE), a zwłaszcza w art. 49, w którym stwierdzono, że „swoboda przedsiębiorczości obejmuje podejmowanie i wykonywanie działalności prowadzonej na własny rachunek, jak również zakładanie i zarządzanie przedsiębiorstwami, a zwłaszcza spółkami”. Ponadto, art. 50, ust 1. TFUE stwierdza, iż „w celu urzeczywistnienia swobody przedsiębiorczości w odniesieniu do określonego rodzaju działalności Parlament Europejski i Rada, stanowiąc zgodnie ze zwykłą procedurą prawodawczą i po konsultacji z Komitetem Ekonomiczno-Społecznym, uchwalają dyrektywy".

TFUE rozwija pojęcie swobody przedsiębiorczości, natomiast go nie definiuje. Obowiązek ten spoczął na Trybunale Sprawiedliwości, który w orzeczeniu w sprawie Factortame stwierdził, iż jest to „samodzielne i rzeczywiste wykonywanie działalności gospodarczej przy pomocy trwałego urządzenia w innym państwie członkowskim na czas nieokreślony”. Na tej podstawie wyróżnić można trzy elementy pojęcia swobody przedsiębiorczości, tj. (Witwicka 2011): 
- samodzielność działalności gospodarczej: ze swobody przedsiębiorczości korzystać mogą osoby prowadzące samodzielną działalność gospodarczą, tzn. na własny koszt i na własne ryzyko, zwłaszcza w formie tzw. samozatrudnienia, co odróżnia tę swobodę od swobody przepływu pracowników;

- trwałość: rozumiana jako trwałość organizacyjna, czyli założenie działalności oraz jej prowadzenie w innym państwie, uczestniczenie w sposób ciągły i stały w jego życiu gospodarczym;

- transgraniczność: ochronie swobody przedsiębiorczości podlega jedynie działalność gospodarcza o charakterze transgranicznym, tzn. wykonywana na terytorium innego państwa członkowskiego.

O swobodzie przedsiębiorczości w UE przesądzają także postanowienia zawarte w Karcie Praw Podstawowych Unii Europejskiej, a w szczególności art. 16, w którym uznano „wolność prowadzenia działalności gospodarczej zgodnie z prawem UE oraz ustawodawstwami i praktykami krajowymi” i art. 45 dotyczący swobody przemieszczania się i pobytu.

\section{PrZEDSIĘBIORSTWA EUROPEJSKIE WOBEC WSPÓŁCZESNYCH WYZWAŃ SPOŁECZNO-GOSPODARCZYCH}

Procesy integracyjne i konsolidacyjne w gospodarce odbywają się na tle przeobrażeń społeczno-gospodarczych, które determinują zachowania przedsiębiorstw (podmiotów gospodarczych). Przedsiębiorstwa dostosowują się zatem do nowych warunków, wśród których do najistotniejszych zaliczyć można globalizację, zmiany demograficzne, postęp techniczny i informatyzację.

Globalizacja - ściślejsza integracja krajów świata - wywołuje potrzebę rozszerzania działań zbiorowych, współpracy ludzi i krajów w rozwiązywaniu wspólnych problemów (Stiglitz 2007: 39). Rynek narodowy i państwo narodowe okazują się nagle za małe, zbyt ograniczone, podobnie jak to było na początku ery nowoczesnej, gdy kapitalizm rynkowy wykorzenił gospodarkę feudalną i wymusił przejście od rządów opartych na miastach-państwach do nowoczesnych rządów na poziomie państwa narodowego. Tym razem próbie zostały poddane gospodarka rynkowa, na której miejsce wkracza gospodarka sieciowa (network economy), oraz państwo narodowe, które jest częściowo zastępowane przez regionalne przestrzenie publiczne, takie jak Unia Europejska (Rifkin 2005: 221-222). Jak zauważył Denis de Rougemont: „decydujące granice suwerenności zakreśla nie prawo, ale konkretna rzeczywistość danej epoki, techniczna, ekonomiczna i polityczna. Wynika z tego, że suwerenność narodowa w odniesieniu do stosunków zewnętrznych istnieje tylko jako pewne obsesyjne, pseudoreligijne złudzenie" (Rougemont 1995: 119). Konsekwencją takich zmian jest zatem sytuacja, w której znaczna cześć, o ile nie większość, instrumentów politycznej i ekonomicznej strategii jest poza możliwością interwencji rządów. Państwo narodowe „,...] okazuje się niezdolne do zaspokojenia konkretnych potrzeb naszej epoki, a to dlatego, że jest ono zarazem za małe w stosunku do świata i za duże w stosunku do regionów i nie odpowiada - chyba tylko przypadkiem - żadnemu obszarowi określonemu naturalną sytuacją 
ekonomiczną bądź jakimś racjonalnym programem” (Rougemont 1995: 117). We współczesnym świecie, może dojść do sytuacji w której poszczególne państwa narodowe przestaną funkcjonować jako jednostki operacyjne i taktyczne (Maśloch 2012a).

Postępująca globalizacja w istotny sposób wpływa także na polaryzację regionalną. Wyraźne preferencje inwestorów upoważniają do stwierdzenia, że kapitał zagraniczny włącza w procesy globalizacji przede wszystkim regiony silne. Warto tutaj przypomnieć stwierdzenie Z. Baumana, który zauważył, że „immanentną częścią globalizacji jest postępująca segregacja przestrzenna, separacja oraz wykluczenie" (Bauman 2000: 7). Współcześnie charakterystyczną cechą otoczenia światowego jest nasilający się proces koncentracji kapitału, który uwidacznia się w kształtowaniu coraz potężniejszych ponadnarodowych korporacji przemysłowych, finansowych, usługowych i in. Obejmują one swoim zasięgiem coraz to rozleglejsze obszary oddziaływania i wpływają w głównej mierze na różnicowanie światowej przestrzeni gospodarczej, społecznej i kulturowej (Zioło 1996: 183-191).

Na rynku obserwujemy zatem silną rywalizację pomiędzy poszczególnymi regionami, wspartą staraniami państwa, mającymi na celu przyciągnięcie na swój obszar jak najwięcej kapitału korporacyjnego. W obliczu procesów globalizacji małe i dysponujące stosunkowo niewielkimi funduszami regiony znajdują się w bardzo ciężkim położeniu. Uwzględniając olbrzymi kapitał jakim dysponują poszczególne korporacje transnarodowe, trudno się spodziewać, aby regiony były traktowane jako równorzędny partner (Sala 2008: 58). Ten mechanizm daje największe preferencje regionom centralnie położonym, nasyconym nowoczesnymi technologiami i dysponującym dobrze rozwiniętym kapitałem ludzkim.

Nowe czasy nieubłaganie napierają na wszelkiego rodzaju hierarchie, czy to w świecie polityki, czy wielkich przedsiębiorstw, i zaczynają je niszczyć. Przejście do gospodarki opartej na wiedzy, która „umacnia” jednostki ludzkie, dając im dostęp do informacji, podważyło wielkie i sztywne struktury biurokratyczne, które za pomocą przepisów, zaleceń i przymusu usiłowały kontrolować wszystko, co leżało w ich polu działania (Fukuyama 2000: 13-14).

Obecne czasy identyfikowane w literaturze przedmiotu jako ,wiek dostępu” (Rifkin 2003) czy „wielki wstrząs” (Fukuyama 2000), wymuszają zupełnie nowe podejście ze strony państwa i przedsiębiorstw do problemów gospodarczych. Sukces ekonomiczny w gospodarce dostępu zależy w mniejszym stopniu od poszczególnych rynków wymiany dóbr, natomiast ważniejsze jest ustanawianie długofalowych relacji (Rifkin 2003: 9). Na wejście W wiek informacji składa się wiele związanych ze sobą elementów. W gospodarce usługi stopniowo wypierają wytwórstwo jako źródło dochodu (Fukuyama 2000: 13).

Współcześnie nastąpiła istna eksplozja wolności wyboru: mamy dziś łatwy dostęp do wielu kanałów telewizyjnych, tanich miejsc zakupów czy przyjaciół poznanych przez Internet. Rola informacji i ludzkiej inteligencji, które człowiek spożytkuje konstruując coraz bardziej wyrafinowane maszyny, staje się coraz większa i praca umysłowa wypiera pracę fizyczną. Produkcja ulega globalizacji w miarę jak tania technologia informacyjna coraz bardziej ułatwia przepływ informacji przez granice państwowe, a błyskawiczna komunikacja za pomocą telewizji, radia, faksu oraz poczty elektronicznej narusza odrębność istniejących od dawna społeczności kulturowych (Rifkin 2003: 13). Gospodarka rynkowa musi zatem zmierzyć się z nowym, sieciowym modelem organizacji handlu i przemysłu. Równolegle 
obok państwa narodowego zaczynają kształtować się nowe formy regionalnego i globalnego zarządzania, które lepiej przesuwają nowości technologiczne, a także zmiany ludzkiej świadomości charakteryzujące erę globalizacji (Rifkin 2005: 128-129).

Powyższe tendencje dodatkowo wzmacniane są przez zmiany demograficzne zachodzące w UE. Co roku w Europie właściciela zmienia około 450 tys. przedsiębiorstw. Szacuje się, że jednej trzeciej z tych przejmowanych przedsiębiorstw grozi upadek. Oznacza to utratę 600 tys. miejsc pracy rocznie. Ocenia się również, że jedna trzecia europejskich właścicieli przedsiębiorstw (czyli około 690 tys. przedsiębiorstw zapewniających 2,8 miliona miejsc pracy) w najbliższych latach przejdzie na emeryturę. Istnieje ryzyko, że wiele z tych świetnie prosperujących przedsiębiorstw nie zostanie przejęta, chyba że ich właściciele poczynią stosowne przygotowania przed emeryturą i pokonają trudności związane z przekazaniem własności (Przeniesienie).

Mając na uwadze powyższe tendencje, należy uznać proces konsolidacji europejskich przedsiębiorstw za nieunikniony. Należy przy tym pamiętać, że koncentracje przedsiębiorstw, rozumiane jako przekształcenie własnościowe przedsiębiorców, są naturalnym zjawiskiem gospodarczym. Mogą one przybierać następujące formy:

- Fuzji (połączenia),

- Przejęcia kontroli,

- Utworzenia wspólnego przedsiębiorstwa,

- Nabycia przez przedsiębiorcę części lub całości mienia innego przedsiębiorcy.

W literaturze przedmiotu wymienia się wiele motywów konsolidacji, fuzji i przejęć (Steiner 1975: 30-33). Niewątpliwie na podjęcie decyzji o fuzji/przejęciu wpływa wiele czynników, takich jak (Strategor 1997: 220-222):

\section{Cechy sektorowe:}

- Stopień dojrzałości danej dziedziny,

- Siła barier na wejściu,

- Skłonność przedsiębiorstw do wzrostu wewnętrznego i zewnętrznego.

Względy taktyczne:

- Gra z czasem (wzrost zewnętrzny umożliwia szybszy zwrot nakładów inwestycyjnych niż wzrost wewnętrzny),

- Neutralizacja konkurenta,

- Dostępność celów,

- Rynkowa dostępność aktywów.

Dzięki przeprowadzonym procesom konsolidacyjnym możliwe staje się uzyskanie wielu rezultatów, wśród których do najistotniejszych należy zaliczyć:

\section{Synergię w obszarze know-how:}

- Grupowa segmentacja klientów,

- Wewnętrzny benchmarking,

\section{Synergię w obszarze efektywności kapitału:}

- Koncentracja kapitału,

- Stworzenie systemu zabezpieczeń, ubezpieczeń i poręczeń, 


\section{Synergię w obszarze posiadanej oferty:}

- Rozszerzanie zakresu oferty,

- Korzystanie z silniejszej pozycji rynkowej - w tym monopolistycznej,

- Komplementarność ofert,

- Cross-selling,

Synergię w obszarze efektywności operacyjnej:

- Integracja systemów informatycznych,

- Scentralizowane zarządzanie ryzykiem,

- Redukcja obciążeń fiskalnych,

- Konsolidacja badań i prac rozwojowych/wdrożeniowych,

- Konsolidacja kanałów dystrybucji,

Synergię w obszarze wizerunku:

- Wykorzystanie siły marki nadrzędnej,

- Centralny marketing marki.

Złożoność procesów fuzji i przejęć określają: ich struktura wyznaczona przez logiczną i czasową sekwencję decyzji i działań, a także przebieg zmian oraz rodzaj i charakter skutków wywoływanych przez te zmiany. Procesom przejęć i fuzji towarzyszy także wiele problemów społecznych i organizacyjnych. Trudno jest rozdzielić te problemy, ponieważ są one wkomponowane w strukturę tych procesów (Zając 2009: 145). Niemniej jednak, jednym z kluczowych problemów jest jakość systemu prawnego w jakim funkcjonują przedsiębiorstwa. Proces regulacji prawnych w zakresie funkcjonowania przedsiębiorstw i prowadzenia działalności gospodarczej nieustannie ulega zmianom. Dla powodzenia zmian zachodzących obecnie w sferze przedsiębiorczości, szczególne znaczenie mają regulacje prawne w zakresie:

- Procesu zakładania przedsiębiorstw,

- Form prawnych prowadzenia działalności gospodarczej,

- Dostępu przedsiębiorstw do kapitału i rynków kapitałowych,

- Dostępnych form wsparcia dla przedsiębiorców i przedsiębiorstw - zarówno w zakresie kapitałowym, organizacyjnym, jak i strukturalnym,

- Systemu podatkowego,

- Jakości administracji,

- Standaryzacji i normalizacji.

Wychodząc naprzeciw powyższym wyzwaniom i korzystając ze swoich uprawnień, Parlament Europejski i Rada zaproponowały przedsiębiorcom z UE nowe ponadnarodowe struktury organizacyjne przedsiębiorstw.

Cecha ponadnarodowości jest konsekwencją zastosowania rozporządzenia jako metody regulacji; przyjęte przez ten akt prawa wspólnotowego rozwiązania stają się wspólne dla systemów prawa krajowego państw członkowskich Unii Europejskiej. Wykorzystanie nadrzędnego charakteru prawa unijnego wobec narodowych porządków prawnych daje więc możliwość przezwyciężenia niedogodności, jakie wiążą się z krajowym charakterem unormowania spółek i stworzenia ramy prawnej adekwatnej do pożądanego europejskiego wymiaru wspólnotowych przedsiębiorstw (Bilewska 2006: 15-16). 
Niewątpliwie z punktu widzenia problemu konsolidacji przedsiębiorstw w UE najistotniejszymi ponadnarodowymi strukturami organizacji przedsiębiorstw są spółki europejskie, spółdzielnie europejskie i europejskie spółki prywatne. Podstawy prawne i kapitał założycielski paneuropejskich przedsiębiorstw zaprezentowano w tab. 1.

Tab. 1. Podstawy prawne i kapitał założycielski paneuropejskich przedsiębiorstw

\begin{tabular}{|c|c|c|}
\hline Skrót & Prawo UE/krajowe & $\begin{array}{c}\text { Kapitał } \\
\text { założycielski }\end{array}$ \\
\hline \multicolumn{3}{|c|}{ Spółka europejska (Societas Europea) } \\
\hline \multirow[t]{2}{*}{ SE } & $\begin{array}{l}\text { - Rozporządzenie Rady (WE) nr 2157/2001 z dnia } 8 \text { października } \\
2001 \text { r. w sprawie statutu spółki europejskiej (SE). } \\
\text { - Dyrektywa Rady 2001/86/WE z dnia } 8 \text { października } 2001 \text { r. uzupeł- } \\
\text { niająca statut spółki europejskiej w odniesieniu do uczestnictwa pra- } \\
\text { cowników. }\end{array}$ & \multirow[t]{2}{*}{120000 euro } \\
\hline & $\begin{array}{l}\text { - Ustawa z } 4 \text { marca } 2005 \text { r. o europejskim zgrupowaniu interesów } \\
\text { gospodarczych i spółce europejskiej (Dz. U. } 2005 \text { nr } 62 \text { poz. 551). }\end{array}$ & \\
\hline \multicolumn{3}{|c|}{ Spółdzielnia europejska (European Cooperative Society) } \\
\hline \multirow[t]{2}{*}{ SCE } & $\begin{array}{l}\text { - Rozporządzenie Rady (WE) nr 1435/2003 z dnia } 22 \text { lipca } 2003 \text { r. } \\
\text { w sprawie statutu spółdzielni europejskiej (SCE). } \\
\text { - Dyrektywa Rady 2003/72/WE z dnia } 22 \text { lipca } 2003 \text { r. uzupełniająca } \\
\text { statut spółdzielni europejskiej w odniesieniu do zaangażowania pra- } \\
\text { cowników. }\end{array}$ & \multirow[t]{2}{*}{30000 euro } \\
\hline & $\begin{array}{l}\text { - Ustawa z dnia } 22 \text { lipca } 2006 \text { r. o spółdzielni europejskiej (Dz. U. } \\
\text { z dnia } 22 \text { sierpnia } 2006 \text { r.) }\end{array}$ & \\
\hline \multicolumn{3}{|c|}{ Europejska spółka prywatna (Societas Privata Europaea) } \\
\hline SPE & $\begin{array}{l}\text { - Wniosek dotyczący rozporządzenia Rady z dnia } 25 \text { czerwca } 2008 \text { r. } \\
\text { w sprawie statutu europejskiej spółki prywatnej. }\end{array}$ & $\begin{array}{l}\text { Minimalna } \\
\text { wysokość kapita- } \\
\text { łu zakładowego } \\
1 \text { euro }\end{array}$ \\
\hline
\end{tabular}

Źródło: opracowanie własne

Rozważając ideę konstrukcji paneuropejskich przedsiębiorstw należy zwrócić szczególną uwagę na ich otwarty, międzynarodowy i transparentny charakter oraz możliwość funkcjonowania i podejmowania działań gospodarczych na terenie całej UE. Przykładem może tu być spółka europejska, gdzie jak wskazują dotychczasowe doświadczenia przedsiębiorstw, decyzja o założeniu lub niezałożeniu SE zależy od konkretnego „przypadku biznesowego”, tj. opiera się na szeregu przyczyn istotnych dla danego przedsiębiorstwa w określonej sytuacji. Przyczyny te mogą być różne i dlatego trudno jest wskazać ogólną tendencję, która dotyczyłaby wszystkich przedsiębiorstw. Niektóre powody wydają się jednak mieć na ogół większe znaczenie niż inne, niektóre zaś wydają się być bardziej istotne w niektórych państwach członkowskich i sektorach działalności niż w innych. Do czynników zidentyfikowanych przez przedsiębiorstwa jako pozytywne zaliczono (Stosowanie 2010):

- Europejski wizerunek SE,

- Ponadnarodowy charakter SE, 
- Możliwość przeniesienia siedziby statutowej,

- Możliwość wykorzystania formy SE jako środka do przeprowadzenia transgranicznego łączenia spółek,

- Potencjał SE w zakresie reorganizacji i upraszczania struktury grupy,

- Silniejszą pozycję w negocjacjach z bankami i przy składaniu ofert w ramach wsparcia finansowego UE),

- Zalety wynikające ze stosowania elastycznych przepisów dotyczących SE w zakresie uczestnictwa pracowników w państwach członkowskich, w których kwestie te są regulowane w ramach bezwzględnie obowiązujących przepisów.

Formuła spółki europejskiej szczególnie popularna stała się w Republice Federalnej Niemiec i Republice Czeskiej. Przykłady funkcjonujących spółek europejskich, takich jak STRABAG SE, Allianz SE, BASF SE, Porsche SE, MAN SE, Aviva Insurance Europe SE, E.ON SE, i wielu innych, jednoznacznie świadczą o atrakcyjności tej formy prawnej. Liczba SE zarejestrowanych w UE w latach 2004-2012 została zaprezentowana w tabeli 2.

Tab. 2. Liczba SE w UE

\begin{tabular}{|c|c|c|c|c|c|c|c|c|c|}
\hline Lata: & 2004 & 2005 & 2006 & 2007 & 2008 & 2009 & 2010 & 2011 & 2012 \\
\hline $\begin{array}{c}\text { Liczba } \\
\text { SE: }\end{array}$ & 7 & 22 & 54 & 138 & 307 & 472 & 679 & 1043 & 1602 \\
\hline
\end{tabular}

Źródło: opracowanie własne na podstawie http://www.worker-participation.eu

W Polsce na dzień 31.12.2012 r. zostały zarejestrowane zaledwie dwie spółki europejskie, którymi są: MCAA SE i AmRest Holdings SE. Podobnie jak w przypadku spółek europejskich, nikłym zainteresowaniem w Polsce cieszy się spółdzielnia europejska.

\section{PrZEDSIĘBIORSTWA PANEUROPEJSKIE A SPRAWA POLSKA}

Jak zauważył P. Kotler, ,szybkie zmiany technologii i uwarunkowań rynkowych zmuszają firmy do wypracowania bardziej elastycznych struktur oraz nowych form organizacji, opartych na wzroście wewnętrznym oraz zewnętrznej sieci powiązań” (Kotler 1999: 441). Analizując problem funkcjonowania paneuropejskich form prowadzenia działalności gospodarczej należy zwrócić uwagę na ich otwarty, elastyczny charakter, umożliwiający budowanie wzajemnych powiązań i zdolność do współpracy w układach: jeden do jednego, jeden do wielu i wielu do wielu, których efektem końcowym może być stworzenie silnej grupy kapitałowej. W tej sytuacji, możliwość funkcjonowania przedsiębiorstw w omawianych, nowych formach prawnych, stwarza przed Polską i polskimi przedsiębiorcami zarówno szereg szans jak i zagrożeń.

Po stronie szans jakie otwierają przedsiębiorstwa paneuropejskie dla Polski należy zaliczyć niewątpliwie ich europejski wizerunek oraz ponadnarodowy charakter, potencjał w zakresie reorganizacji i upraszczania struktury przedsiębiorstwa oraz zalety wynikające ze stosowania elastycznych przepisów w zakresie uczestnictwa pracowników w państwach 
członkowskich, w których kwestie te są regulowane w ramach bezwzględnie obowiązujących przepisów. Nie bez znaczenia jest także silniejsza pozycja w negocjacjach z bankami i przy składaniu ofert w ramach wsparcia finansowego z programów pomocowych UE, co w perspektywie nowego okresu programowania na lata 2014-2020 wydaje się niezmiernie istotne (Maśloch 2012b: 202-211).

Zaprezentowane formy prawne stwarzają możliwości nie tylko dla nowych podmiotów gospodarczych, ale również tworzą szanse dla restrukturyzowanych przedsiębiorstw. Jak wynika z dotychczasowych doświadczeń gospodarczych, restrukturyzacja polskich przedsiębiorstw niesie ze sobą wiele problemów gospodarczych i społecznych (Maśloch 2011). Trudna sytuacja finansowa jednostek samorządu terytorialnego uwidacznia te problemy zwłaszcza wśród przedsiębiorstw komunalnych (Grzymała 2011), dla których coraz częściej szuka się nowych form funkcjonowania i organizacji. Wykorzystanie w procesach restrukturyzacyjnych paneuropejskich form przedsiębiorstw może przyczynić się do uproszczenia i obniżenia kosztów restrukturyzacji oraz uczynić firmę bardziej elastyczną.

Nowe formy prawne funkcjonowania przedsiębiorstw w UE, w praktyce oznaczają zupełnie nowe warunki funkcjonowania przedsiębiorstw, w tym m.in. intensyfikowanie tzw. efektu Delaware. Niewątpliwym zagrożeniem dla gospodarki polskiej jest zatem możliwość wyboru siedziby głównej przedsiębiorstwa paneuropejskiego w dowolnym państwie UE w celu wykorzystania optymalizacji opodatkowania dochodów czy skorzystania z form wsparcia.

Należy mieć na uwadze, że o sukcesie współczesnych przedsiębiorstw decyduje ich innowacyjność - w tym głównie innowacyjność organizacyjna. W sytuacji, gdy zgodnie $\mathrm{z}$ raportem The Global Competitiveness Report 2011-2012 (The Global 2012) Polska w wielu aspektach funkcjonowania gospodarki odbiega od europejskich liderów, a w rankingu Wolności Gospodarczej (IEF) w 2012 r. została sklasyfikowana na 64 miejscu - w grupie państw zaliczanych do kategorii 3, w zasadzie bez wolności gospodarczej (jest to jedno z najgorszych miejsc jakie zajęły państwa UE - dla porównania, RFN sklasyfikowana została na 26 miejscu, a Republika Czeska na 30 miejscu [Index 2012]), brak jakiegokolwiek zainteresowania paneuropejskimi formami prawnymi przedsiębiorstw w perspektywie wieloletniej może mieć groźne konsekwencje nie tylko dla budżetów i gospodarek poszczególnych jednostek samorządu terytorialnego, ale także całego państwa. Przedsiębiorstwa chcąc konkurować na rynku będą zmuszone do poszukiwania nowych, innowacyjnych rozwiązań organizacyjnych i finansowych. Takie możliwości dają m.in. paneuropejskie formy prawne przedsiębiorstw, które poprzez swobodny wybór siedziby i obszaru działania na terenie UE, doprowadzają do sytuacji, w której z państw/regionów nieprzyjaznych dla przedsiębiorców nastąpi emigracja przedsiębiorstw do miejsc, które zaoferują najkorzystniejsze warunki rozwoju. Dlatego też koniecznym wydaje się stworzenie przez władze publiczne odpowiedniego systemu wsparcia dla przedsiębiorstw w oparciu o paneuropejskie formy prowadzenia działalności gospodarczej, które przy respektowaniu ustalonych zasad będą mogły stworzyć silną grupę kapitałową, będącą istotnym graczem na europejskim rynku.

Należy mieć bowiem na uwadze, że krajowe rezerwy przedsiębiorczości nie funkcjonują poprawnie w sposób automatyczny, lecz tylko wtedy, gdy pozwalają im na to odpowiednie 
instytucje (de Soto 1991: 347). Na funkcjonowanie przedsiębiorstw wpływa zatem jakość instrumentów pośredniego i bezpośredniego oddziaływania, które określa władza ustawodawcza, a wdraża rząd. Duże znaczenie mają tu jakość i stałość stosowanych instrumentów oraz ich przyjazny stosunek do rozwoju przedsiębiorczości. O ich jakości świadczą zwłaszcza częste nowelizacje ustaw i zarządzeń, które są najczęściej wynikiem ich niedopracowania albo reprezentują interesy pewnych grup. Wskazuje to na niski poziom kwalifikacji, a także na niski poziom etyczny osób odpowiedzialnych za ich tworzenie (Zioło 2010: 50). Poza formalnościami związanymi z samą kulturą tworzenia prawa, istotną rolę odgrywają także interpretacje obowiązującego prawa. Jak zauważył Hernando de Soto, w krajach, które przechodziły transformację systemową bardzo często ,[...] bez względu jak dobre miały intencje, dystans pomiędzy nakazami ustaw, a tym, co trzeba by uczynić, aby prawo stało się skuteczne jest wciąż ogromny" (de Soto 2002: 195).

\section{ZAKOŃCZENIE}

Rozwój poprzez konsolidację, fuzje i przejęcia jest od wielu lat jednym z najważniejszych kierunków rozwoju przedsiębiorstw. Problem ten jest niezmiernie ważny zwłaszcza w UE, gdzie procesy demograficzne, społeczne i gospodarcze wymuszają podjęcie radykalnych działań konsolidacyjnych.

Nadszedł wiek informacji. W następnych latach czekają nas nowe, wyrafinowane technologie informatyczne, które przybliżą cywilizację jeszcze bardziej do świata prawie pozbawionego robotników. W rolnictwie, produkcji i usługach maszyny szybko zastępują ludzką siłę roboczą i zapowiadają na połowę XXI w. nadejście gospodarki z produkcją prawie całkowicie zautomatyzowaną. Masowa substytucja ludzi przez coraz nowocześniejsze automaty zmusza państwo do przemyślenia na nowo roli człowieka w społecznym procesie. Określenie dla milionów ludzi nowych możliwości i obowiązków w społeczeństwie bez masowego, tradycyjnego zatrudnienia będzie chyba największym problemem społecznym nowego stulecia (Rifkin 2001: 11). Gdy w XX wieku najcenniejszym zasobem przedsiębiorstwa były posiadane środki produkcji, które przyczyniły się do ponad pięćdziesięciokrotnego wzrostu wydajności pracowników fizycznych, w wieku XXI najwartościowszy z perspektywy organizacji będzie pracownik posiadający duże zasoby wiedzy (Drucker 2009: 145). W „wieku dostępu” coraz istotniejsze okazują się sieci powiązań oraz zdolność do sprawnego w niej funkcjonowania, przy czym obniża się skala połączeń organizacyjnych na rzecz powiązań kapitałowych.

Możliwości budowania takich powiązań sieciowych dają właśnie paneuropejskie przedsiębiorstwa, których otwarta forma pozwala na zaangażowanie niezależnie od posiadanych kapitałów wszystkich gotowych do współpracy podmiotów. Poprzez możliwości podejmowania kooperacji i tworzenia w jej ramach struktur pionowych i poziomych, dają szansę na wszechstronną współpracę na jednolitym rynku europejskim. Brak zainteresowania tymi formami, bez wątpienia naraża nasz kraj na wykluczenie z gry o rozwój i drenaż kapitałów. 
Formuła paneuropejskich form prowadzenia działalności gospodarczej na dzień dzisiejszy nie spotkała się w Polsce z szerokim zainteresowaniem nie tylko w praktyce gospodarczej, ale również w literaturze przedmiotu. W literaturze przeważa pogląd, zgodnie z którym uwypuklona w artykule forma spółki europejskiej w UE ma znaczenie marginalne (Opalski 2011: XLII). Niemniej jednak, jak pokazują dotychczasowe doświadczenia największych europejskich korporacji oraz rosnąca liczba przedsiębiorstw wybierających tę formę prawną, problem wydaje się bardziej poważny. Wskazywane są także wady SE, wśród których wymienia się głównie ,hierarchiczny katalog źródeł prawa, znajdujących zastosowanie do SE, który może prowadzić do niepewności prawnej i stwarzać w praktyce trudności przy ustalaniu normy rozstrzygającej określoną kwestię" (Spółka). W tak postawionej tezie, zdaniem autora trudno raczej doszukiwać się wady po stronie SE, a raczej należy wskazać na słabą znajomość przez polskich przedsiębiorców obowiązującego prawa międzynarodowego.

Brak zainteresowania omawianymi w artykule paneuropejskimi formami prawnymi w konsekwencji doprowadzi do wykluczenia polskich przedsiębiorstw - a tym samym Polski - z gry o rozwój. Bez kompatybilnego systemu z innymi gospodarkami UE, polskie przedsiębiorstwa nie będą w stanie konkurować na rynku UE. Przedsiębiorstwa funkcjonujące bowiem w formach paneuropejskich, jak już wspomniano, dzięki ich otwartemu, elastycznemu charakterowi, umożliwiającemu budowanie wzajemnych powiązań, będą w stanie budować przewagę konkurencyjną stosownie do stojących przed nimi wyzwań.

\section{Literatura / References}

Bauman, Z. (2000). Globalizacja. Warszawa: PIW.

Bilewska, K. (2006). Spótka europejska. Warszawa: LexisNexis.

Dyrektywa 2004/25/WE Parlamentu Europejskiego i Rady z dnia 21 kwietnia 2004 r. w sprawie ofert przejęcia (Tekst mający znaczenie dla EOG).

Drucker, P.F. (2009). Zarzadzanie XXI wieku - wyzwania. Warszawa: MT Biznes Sp. z o.o.

Fukuyama, F. (2000). Wielki wstrzas. Warszawa: Politeja.

Griffin, R.W. (2004). Podstawy zarzadzania organizacjami. Warszawa: PWN.

Grzymała,Z. (2010). Restrukturyzacja sektora komunalnego w Polsce. Warszawa: Oficyna Wydawnicza Szkoła Główna Handlowa Warszawa.

Index of Economic Freedom. (2012, 20 grudnia). Pozyskano z: http://www.heritage.org.

Jednolity rynek Europy XXI wieku, 2007. Komunikat Komisji dla Parlamentu Europejskiego. Rady, Europejskiego Komitetu Ekonomiczno-Społecznego i Komitetu Regionów. Bruksela. $\operatorname{KOM}(2007) 724$ wersja ostateczna.

Karta Praw Podstawowych Unii Europejskiej. (2010/C 83/02)PL 30.3.2010 Dziennik Urzędowy Unii Europejskiej C 83/389.

Kotler, P., Caslione, J.A. (2009). Chaos. Warszawa: MT Biznes Ltd.

Kotler, P., Jatusripitak, S., Maesincee, S. (1999). Marketing narodów. Strategiczne podejście do budowania bogactwa narodowego. Kraków: Wydawnictwo Profesjonalnej Szkoły Biznesu.

Marks, M.L. (1994). From Turmoil to Triumph: new life after mergers, acquisitions and downsizing. New York: Lexington. 
Maśloch, G. (2012a). Kompatybilność systemów ekonometrycznych na podstawie „Nine Keys to a Knowledge Infrastructure" oraz programu ESPON 2013. W: R. Bartkowiak, J. Ostaszewski (red.), Dorobek ekonomii, finansów i nauk o zarzadzaniu oraz jego praktyczne wykorzystanie na przełomie XX i XXI wieku. Warszawa: Oficyna Wydawnicza Szkoła Główna Handlowa Warszawa, 439-448.

Maśloch, G. (2012b). Wybrane problemy realizacji inwestycji w jednostkach samorządu terytorialnego przy udziale środków pomocowych Unii Europejskiej. W: R. Brol (red.), Gospodarka lokalna i regionalna $w$ teorii $i$ praktyce. Wrocław: Prace Naukowe Uniwersytetu Ekonomicznego we Wrocławiu, 202-211.

Maśloch, P. (2011). Restrukturyzacja przedsiębiorstw w Polsce $w$ dobie transformacji i globalizacji. Torun: Wydawnictwo WSB.

Opalski, A. (2011). Europejskie prawo spótek. Wprowadzenie. Warszawa: CH Beck.

Przeniesienie własności. (2012, 20 grudnia). Pozyskano z: http://europa.eu/youreurope/business/exit-strategy/selling-on/index_pl.htm.

Rifkin, J. (2005). Europejskie marzenie. Jak europejska wizja przyszłości zaćmiewa american dream. Warszawa: Nadir.

Rifkin, J., Howard, T. (2008). Entropia. Nowy światopogląd. Katowice: Wydawnictwo Kos.

Rifkin, J. (2001). Koniec pracy. Schytek siły roboczej na świecie i poczatek ery postronkowej. Wrocław: Wydawnictwo Dolnośląskie.

Rifkin, J. (2003). Wiek dostępu. Nowa kultura hiperkapitalizmu, w której płaci się za każdq chwile życia. Wrocław: Wydawnictwo Dolnośląskie.

Rougemont, D. (1995). List otwarty do Europejczyków. Warszawa: Oficyna Wydawnicza Volumen.

Sala, S. (2008). Wpływ procesów globalizacji na region. Prace Komisji Geografii Przemysłu Polskiego Towarzystwa Geograficznego, 10, 55-66.

Silniejszy przemysł europejski na rzecz wzrostu i ożywienia gospodarczego. (2012). Komunikat Komisji do Parlamentu Europejskiego, Rady, Europejskiego Komitetu Ekonomiczno-Społecznego i Komitetu Regionów. Bruksela, dnia 10.10.2012, COM(2012) 582 final.

Spółka europejska (SE). Wolters Kluwer Polska S.A. (2012, 20 grudnia). Pozyskano z: www.meritum.pl.

Soto, H. (1991). Inny szlak. Niewidzialna rewolucja w Trzecim Świecie. Warszawa: Polskie Towarzystwo Współpracy z Klubem Rzymskim.

Steiner, P. (1975). Mergers: Motives, Effects, Policies. University of Michigan Press, 30-33.

Stiglitz, J.E. (2007). Wizja sprawiedliwej globalizacji. Propozycje usprawnień. Warszawa: PWN.

Stosowanie rozporządzenia Rady nr 2157/2001 z dnia 8 października 2001 r. w sprawie statutu spółki europejskiej (SE). Sprawozdanie Komisji dla Parlamentu Europejskiego i Rady. (Tekst mający znaczenie dla EOG), SEK(2010) 1391, Bruksela, dnia 17.11.2010, KOM(2010) 676 wersja ostateczna.

Strategor, zarządzanie firmą. Strategie, struktury, decyzje, tożsamość, 1997, PWE, Warszawa.

The Global Competitiveness Report 2011-2012. (2012, 20 grudnia). Pozyskano z: http://www3.weforum.org/docs/WEF_GCR_Report_2011-12.pdf.

Wersje skonsolidowane Traktatu o Unii Europejskiej i Traktatu o funkcjonowaniu Unii Europejskiej. Dziennik Urzędowy C 83 z 30.3.2010.

Witwicka, A. (2012, 20 grudnia). Swoboda przedsiębiorczości. Pozyskano z: http://www.uniaeuropejska.org. 
Zając, C. (2009). Przejęcia i fuzje jako procesy zmian w przedsiębiorstwie. W: S. Nowosielski (red.), Podejście procesowe w organizacjach. Wrocław: Prace Naukowe Uniwersytetu Ekonomicznego we Wrocławiu, 52.

Zioło, Z. (1996). Model przestrzeni geograficznej i jej znaczenie dla gospodarki przestrzennej. W: U. Wich (red.), Gospodarka-Przestrzeń-Środowisko. Lublin: Wydawnictwo UMCS.

Zioło, Z. (2010). Uwarunkowania kształtowania się procesów transformacji przemysłu i usług. Prace Komisji Geografii Przemystu Polskiego Towarzystwa Geograficznego, 15, 45-60.

Grzegorz Maśloch, dr, Szkoła Główna Handlowa w Warszawie, Katedra Ekonomiki i Finansów Samorządu Terytorialnego.

Zainteresowania naukowe autora koncentrują się na problemach związanych z rozwojem lokalnym i regionalnym, zwłaszcza w aspekcie strategii rozwoju i ich realizacji, inwestycji i planów finansowych oraz przygotowania i realizacji projektów inwestycyjnych, w tym współfinansowanych ze środków UE.

Grzegorz Maśloch, Ph.D., Warsaw School of Economics, Chair of Economics and Local Government Finances.

The scientific interests focus on the problems of local and regional development, especially on the local development strategy and its realization, longtime investments and financial plans, preparing and effectiveness evaluation of the investment projects co-financed by the UE.

adres/address: Szkoła Główna Handlowa w Warszawie

Katedra Ekonomiki i Finansów Samorządu Terytorialnego

budynek M, pok. 307, ul. Madalińskiego 6/8, 02-513 Warszawa, Polska

e-mail: gmaslo@sgh.waw.pl 